\title{
Representation of Female Sexuality and Freedom: Kate Chopin's Selected Short Stories
}

\author{
By Zeenat Sharmin
}

Begum Rokeya University

Abstract- The writer Kate Chopin has written about female sexuality and the restrictions put by marriage as an institution upon the lives of women. Her writings delineate the lives of female characters who are burdened by the relationships they have in society. They are self-assertive and courageous women of the nineteenth century. They are thought to be ahead of their time. They have refused to accept the traditional roles and conventions of the society and have shown the deepest drives of their hearts. Chopin has explored these female souls as a woman writer. Her first attempt is to highlight the sense of female freedom and a true understanding of their nature in her writings. The purpose of this article is to analyze the representation of female sexuality and freedom in Kate Chopin's selected short stories entitled "The Story of an Hour," "The Storm," and "A Pair of Silk Stockings".

Keywords: female sexuality, female freedom, conventions, marriage.

GJHSS-A Classification: FOR Code: 950199

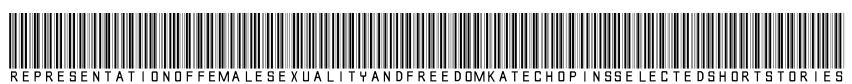

Strictly as per the compliance and regulations of:

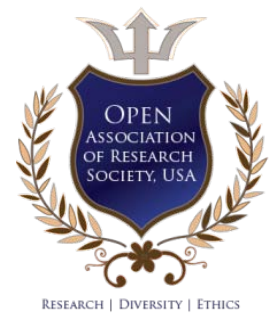

(c) 2020. Zeenat Sharmin. This is a research/review paper, distributed under the terms of the Creative Commons AttributionNoncommercial 3.0 Unported License http://creativecommons.org/licenses/by-nc/3.0/), permitting all non-commercial use, distribution, and reproduction in any medium, provided the original work is properly cited. 


\title{
Representation of Female Sexuality and Freedom: Kate Chopin's Selected Short Stories
}

\author{
Zeenat Sharmin
}

Abstract-The writer Kate Chopin has written about female sexuality and the restrictions put by marriage as an institution upon the lives of women. Her writings delineate the lives of female characters who are burdened by the relationships they have in society. They are self-assertive and courageous women of the nineteenth century. They are thought to be ahead of their time. They have refused to accept the traditional roles and conventions of the society and have shown the deepest drives of their hearts. Chopin has explored these female souls as a woman writer. Her first attempt is to highlight the sense of female freedom and a true understanding of their nature in her writings. The purpose of this article is to analyze the representation of female sexuality and freedom in Kate Chopin's selected short stories entitled "The Story of an Hour," "The Storm," and "A Pair of Silk Stockings".

Keywords: female sexuality, female freedom, conventions, marriage.

\section{Discussion}

K ate Chopin is an American writer, whose works are considered ahead of her time and are condemned to be scandalous during her lifetime. Most of the characters in her writings are married women. She has focused on the conditions of these married women within this frame of marriage. She has shown their struggles, pains, sufferings, and desires in her short stories. Though the characters in her writings live in the patriarchal world, we find a silent revolt from their parts to accept their roles as expected by society. They do not protest violently, but their sense of freedom and sexuality are expressed by their actions. This paper will analyze the activities and desires of Chopin's female characters through which she has deconstructed the traditional ideas of ideal women. In doing this, she has also shown women's rights to their bodies and souls. Her female characters nourish a deep desire to live freely and to enjoy their sexual desires freely. They do not confine themselves to the role of submissive wives and mothers. They search for an identity free from male subjugation. Chopin has talked about female sexuality and freedom in a period where these were treated as taboos.

In her short story "The Story of an Hour," Chopin has presented the beautiful picture of a female's sense of freedom. It is the tale of a wife who is called 'Mrs. Mallard', her hope to lead an independent life truly for herself when she receives the shocking news of the reported death of her husband in a train accident. The story shows the real picture of marriage and the bindings it imposes on wives. The death news of her husband creates a sense of awareness for freedom in the central character. She at first mourns briefly, then a sense of relief and exaltation overtake her grief. She goes to her room and finally sits on the armchair facing the open window. She is haunted by something: "There was something coming to her and she was waiting for it, fearfully. What was it? She did not know; it was too subtle and elusive to name. But she felt it, creeping out of the sky, reaching toward her through the sounds, the scents, and the color that filled the air." (Chopin, "The Awakening" 214)

Here Chopin has tried to show the central character's emotion and condition after getting the death news of her husband. This reaction is not a common reaction expected from a traditional woman. She welcomes the strange feelings. This is her awakening moment; she regains her freedom as a woman. The open window is the symbol of freedom in this story. It is for her the path to inspiration and enlightenment. She drinks the very elixir of life through that window. The setting of the room with the window suggests a new life filled with freedom. Her emotions are expressed in the following lines: "When she abandoned herself a little whispered word escaped her slightly parted lips. She said it over and over under her breath: free, free, free!"....... Her pulses beat fast, and the coursing blood warmed and relaxed every inch of her body. She did not stop to ask if it were or were not a monstrous joy that held her." (Chopin, "The Awakening" 214)

It is like a 'monstrous joy' for her that she is free and can lead her life according to her wish. Her relief and sense of freedom expose the fact of domination under the veil of marriage. Marriage is an institution by which male power is manifested and maintained. The domination ranges from physical brutality to control of consciousness. Adriene Rich in her essay "Compulsory Heterosexuality and Lesbian Existence" has suggested:

Some of the forms by which male power manifests itself are more easily recognizable as enforcing heterosexuality on women than are others. Yet each one I have listed adds to the cluster of forces within which women have been convinced that marriage and sexual orientation toward men are inevitable-even if unsatisfying or oppressivecomponents of their lives. The chastity belt; child marriage; erasure of lesbian existence (except as exotic and 
perverse) in art, literature, film; idealization of heterosexual romance and marriage-these are some fairly obvious forms of compulsion, the first two exemplifying physical forces, the second two controls of consciousness. (209)

In the short story, the emotions of Mrs. The mallard is expressed by the lines: "There would be no one to live for her during these coming years; she would live for herself. There would be no powerful will bending hers in that blind persistence with which men and women believe they have a right to impose a private will upon a fellow creature." (Chopin, "The Awakening" 214)

So we can understand Mrs. Mallard's desire to live for herself only. She is disturbed by the traditional roles she has to fulfill. Rich in her essay "When We Dead Awaken" has said:" But to be a female human being trying to fulfill traditional female functions in a traditional way is in direct conflict with the subversive function of imagination. The word traditional is important here. There must be ways, and we will be finding out more and more about them, in which the energy of creation and the energy of relation can be united." (174)

Mrs. Mallard can completely feel her inner self. She utters, "Free! Body and soul free!"(Chopin, "The Awakening" 214)This line clearly portrays the deep urge in her mind for freedom. She cannot manage to make a bridge between the energy of relation and energy of creation. That is why when she hears the death news of her husband, she feels free. "She breathed a quick prayer that life might be long. It was only yesterday she had thought with a shudder that life might be long." (Chopin, "The Awakening" 214) By this feeling of Mrs. Mallard, readers can understand that she is trapped because of the imposed gender roles in society. Her sense of freedom after the death of her husband gives readers a shock. But the writer has shown her feelings, which reflect that she is tired of the imposed social roles. Though the readers do not get any kind of physical domination in her married life, they can feel the presence of a threat of male dominance.

Mrs. Mallard's earlier name was Louise. But after marriage, she has become 'Mrs. Mallard'. She has lost her identity. Simone de Beauvoir, in her book The Second Sex has presented her ideas about marriage in a chapter called "The Married Woman." According to her, "Marriage has always been a very different thing for man and for woman." (445) "She takes his name, she belongs to his religion, his class, his circle, she joins his family, and she becomes his 'half'." (449) So in society a woman internalizes the fact that they can be controlled by their husbands. They are the 'others', and the males are the 'selves'. They have to follow certain fixed conventions of the society that tell women to forget about herself, to ignore her freedom, to be a caring wife and mother. After following these, a woman can be a true woman. Since men were fixed by God to be women's superior, a woman must submit to her husband. As Beauvoir has mentioned in her "Introduction" of The Second Sex: "Thus, woman may fail to lay claim to the status of subject because she lacks definite resources, because she feels the necessary bond that ties her to man regardless of reciprocity, and because she is often very well pleased with her role as the "Other"."(21)

So Louise can understand or feel her inner self only after the false news of the death of her husband. She expects to live a free life, but ultimately this is not possible, which is suggested by the ending. A female cannot search for her freedom in the patriarchal world. So she cannot finally achieve the desired freedom. She dies while her husband turns out to be alive. Her death is misinterpreted by the doctor as "a joy that kills". Because society is not ready to give her freedom, she can achieve that only at the expense of her death.

Kate Chopin has written "The Storm" in 1898. It is the sequel of the short story "At the Cadian Ball". She has not made any effort to publish the story during her lifetime. Because in the late 1800 and early 1900, this type of work was considered scandalous. This story narrates the explicit extra marital relationship between two persons Alce'e and Calixta. These two characters have met one another in the story "The Cadian Ball" and have got married to two other persons. As the story "The Storm" moves, we see they cannot resist their sexual impulses for one another. The storm outside the house is the external presentation of these characters' inner passion for one another. At the very opening of the story, Calixta is seen to perform a household duty like sewing. "She was greatly occupied and did not notice the approaching storm." (Chopin, "The Norton" 1604)

Her husband and child are away from home. She is worried about their return. Beauvoir, in the chapter "The Married Woman" in her book The Second Sex, has stated: "Woman's function is also to satisfy a male's sexual needs and to take care of his household. These duties placed upon woman by society are regarded as a service rendered to her spouse: in return, he is supposed to give her presents, or a marriage settlement, and to support her." (447)

She is the mistress of the house. The outside world is for males. As Beauvoir says, "marriage enslaves her to a man, but it makes her mistress of a home." (450) At this very stage, Calixta sees Alce'e At her doorstep. He wants to take shelter in her house. Calixta agrees. Beauvoir says: "The woman is doomed to immorality, because for her to be moral would mean that she must incarnate a being of superhuman qualities: the 'virtuous woman' of proverbs, the 'perfect mother', the 'honest woman', and so on Let her but think, dream, sleep, desire, breath without permission and she betrays the masculine ideals. That is why many wives let themselves go, 'are themselves'. Only in the absence of their husbands." (492) 
When Alce'e enters and grabs the cloths of Calixta's husband and child, it creates an impression on the readers' minds that something mysterious will happen. Calixta and Alce'e had once an admiration for each other, but now she is a married woman, she is a mother. She is not expected to have any passionate desire for Alce'e. But as the story goes on, we see Calixta refuses these codes by freely showing her natural. Her sense of sexuality and eroticism are expressed by her womanly figure, seductive voice, and tantalizing eyes. She is confident and provocative. "She was a little fuller of figure that five years before when she married; but she had lost nothing of her vivacity. Her blue eyes still retained their melting quality; and her yellow hair, disheveled by the wind and rain, kinked more stubbornly that ever about her ears and temples." (Chopin, "The Norton" 1604)

She feels frightened by the storm and thunder. She is given support by Alce'e. They finally cannot resist past infatuation. Both of them surrender. This passionate description portrays the nature of ' $e$ 'criture fe'minine', a female style of writing: "Her lips were as red and moist as pomegranate seed. Her white neck and a glimpse of her full, firm bosom disturbed him powerfully." (Chopin, "The Norton" 1605) Chopin has described the lips and parts of Calixta's body to show the sexuality she feels with Alce'e. As a woman she is not permitted to have sex outside the frame of marriage. But she can feel the sensations as an individual, and she does not want to hide it. In 1898 Chopin was ahead of her time to write about this kind of female sexuality. Hélène Cixous has stated in her "The Laugh of the Medusa", "Woman must write herself; must write about woman and bring woman to writing." (2039) So as a woman it is expected from Chopin to show the sense of female freedom and sexuality in her writings. Calixta in "The Storm" is such a character who can be viewed as a scandalous character by the conventions of society, but she enjoys her sense of sexuality. We do not get the picture of her sexual life with her husband. But how she feels with Alce'e gives a clear idea of her happiness with him and her dissatisfaction with her husband. "Her firm, elastic flesh that was known for the first time its birthright, was like a creamy lily that the sun invites to contribute its breath and perfume to the underlying life of the world."(Chopin, "The Norton" 1605)

Cixous says, "Write yourself. Your body must be heard."(2043) So through the description of the body of Calixta, Chopin has tried to establish the identity of women as individual human beings. "When he touched her breasts they gave themselves up on quivering ecstasy, invites his lips. Her mouth was a fountain of delight. And when he possessed her, they seemed to swoon together at the very borderland of life's mystery." (Chopin, "The Norton" 1605)

So sex is depicted as a natural force by the writer in the story. None of the characters feel shame for their activities. Both of them have enjoyed the sex, which is far from the Victorian concept of sexual pleasure. As a woman Calixta feels satisfied during this sexual intercourse. But according to the Victorian concept, sex should be treated by women as a duty rather than a pleasure. Her satisfaction does not bring any sign of disturbance in her attitude with her husband after the incident. She becomes joyous in her treatment with her family. That brief sexual freedom changes her. She feels free from the suppression of marriage. She becomes a more caring wife and mother after the incident. The same thing happens with Alce'e. He writes a loving letter to his wife, who is away from him. He tells her to stay in her house a month longer if she likes. Her wife also likes the freedom to stay in her parents' house, which she has missed after marriage. "And the first free breath since her marriage seemed to restore the pleasant liberty of her maiden days." (Chopin, "The Norton" 1607) Finally the writer concludes the story with this line: "So the storm passed and everyone was happy." (Chopin, "The Norton" 1607)

In "A Pair of Silk Stockings", Kate Chopin has expressed the theme of a female sense of freedom, responsibility, and identity through the character Mrs. Sommers. The story revolves around how this character gets an amount of money and how she finally spends that. She is presented as a good mother by the writer, who wants to spend the money on the kids' needs. But when she visits the shop, she cannot resist her inner desire to buy things for her. She has bought a pair of silk stockings, a pair of gloves, and two high priced magazines, has taken a decent lunch in a renowned restaurant and watched a drama performance in a theatre. That day is a momentary relief from her daily life. She can forget the conventional role of a mother for a short moment and can try to be herself. As Beauvoir says in her book, "The tragedy of marriage is not that it fails to assure woman the promised happiness-there is no such thing as assurance in regard to happiness-but that it mutilates her; it dooms her to repetition and routine."(496) Mrs. Sommers is a character who is shown to be trapped by this routine life. So when she finds the opportunity, she wants to enjoy her life for a moment. The readers get no sign of Mr. Sommers in the story. This absence of Mr. Sommers suggests that traditionally women are thought to have responsibilities of taking care of children and family rather than sharing an equal footing within the system of marriage. The amount of money also suggests that only money can bring self-esteem and can enhance the individual's sense of freedom. But it is also true that this freedom is for Mrs. Sommers very short-lived. She can escape into a world where she has no one to care for, where she can be only herself. But the reality is she has to return to her family. Chopin does not want to say that Mrs. Sommers will enjoy this sense of freedom for a long time. But she has shown that Mrs. Sommers is an individual before anything else. So when she gets the chance, she wants to do something for her entertainment. She is burdened by the conventional role as a mother, as Beauvoir says, "it usually happens that the birth of a child 
compels them to limit themselves to their role as matron;" (501). She at first is presented as a mother who does not want to misuse the money. "The question of investment was one that occupied her greatly. For a day or two she walked about apparently in a dreamy state, but really absorbed in speculation and calculation. She did not wish to act hastily, to do anything she might afterward regret." (Chopin, "The Awakening"262)

She does not have a chance to think of her own desires. When she touches the silk stockings, she can feel completely different for a moment. "How good was the touch of raw silk to her flesh!" (Chopin, "The Awakening" 265) She, after a long time, can sense the touch of her own body. "Her foot and ankle looked very pretty. She could not realize that they belonged to her and were a part of herself." (Chopin, "The Awakening" 265) Chopin, as a female writer, has presented the experience of a woman here. As Hélène Cixous writes: "By writing herself, woman will return to the body which has been more that confiscated from her, which has been turned into the uncanny stranger on display- the ailing or dead figure" (2043) So the body of women should be presented by the female writers in their writings to explore the experience usually women do have.

In the end, she waits for the cable car and a wish that the cable car would never stop anywhere, but go on and on with her forever. Her situation is clearly understood by her desire. Going to the home is for her going to be fitted with the roles of mother and wife. Her destination suggests the end of her dream and freedom. So she wants to enjoy the bliss of her freedom. She wants that the journey should be longer; it should not be stopped. Her situation can be compared with Louise's in "The Story of an Hour". Both of them have felt a sense of freedom, but they cannot enjoy it for a long time.

Kate Chopin, through these three short stories, has shown the central character's urge to enjoy their lives. Their expressions delineate their frustrations and depressions. They are subjugated within the intuition of marriage. They have lost their identities as human beings. But when the situation comes, they try to regain their individualities. Though these characters are not celebrated during the lifetime of the writer, they can make an impression upon the readers' minds for a long time. Louise dies, Calixta enjoys her body for a short time, and Mrs. Sommers wants to have a never- ending cable car journey. By showing their sense of freedom and sexuality, they establish themselves as individuals in society.

\section{Works Cited}

1. Beauvoir, Simone De. The Second Sex. Trans and Ed. H. M. Parshley. London: Vintage, 1997. Print.

2. Chopin, Kate. The Awakening and Selected Stories. New York: Penguin Books, 1984. Print.

3. ---." The Storm". Ed. Nina Baym. The Norton Anthology of American Literature. New York: Norton, 2003.1603-07. Print.

4. Cixous, Hélène. "The Laugh of the Medusa". Trans. Cohen Keith and Cohen Paula. The Norton Anthology of Theory and Criticism. Ed Vincent B. Leitch. New York: Norton, 2001.2039-56. Print.

5. Rich, Adriene. "When We Dead Awaken: Writing as Re-Vision". Adriene Rich's Poetry and Prose. Ed Gelpi, Barbara Charlesworth and Gelpi, Albert. New York: Norton, 1993. 166-77. Print.

6. Rich, Adrienne. "Compulsory Heterosexuality and Lesbian Existence". Gelpi and Gelpi 203-224. 